\title{
Pengaruh Senam Prolanis terhadap Perubahan Kadar Hemoglobin Sebelum dan Sesudah Senam di Klinik Cempaka Pulogebang Jakarta Timur
}

\author{
Bangun Cholifa Nusantara ${ }^{1}$, Fanny Septiani Farhan² \\ 1) Program Studi Kedokteran, Fakultas Kedokteran dan Kesehatan, Universitas Muhammadiyah Jakarta \\ 2) Departemen Biomedik, Fakultas Kedokteran dan Kesehatan, Universitas Muhammadiyah Jakarta \\ *bangun.nt@gmail.com
}

\begin{abstract}
Background: hemoglobin has the function of transporting oxygen. Aerobic exercise causes tissue to lack oxygen. Tissue hypoxia will stimulate the kidneys to release the hormone erythropoetin. Erythropoetin stimulates the maturation of erythrocytes in the bone marrow. So it will cause an increase in hemoglobin. Prolanis gymnastics (Chronic Disease Management Program) is an aerobic physical exercise which is one of the government programs. This study wanted to determine the effect of prolanis exercises on hemoglobin levels before and after gymnastics. Method: the method used is a quasi-experiment through comparison of subject conditions before treatment with after treatment with 16 respondents. In this study, the number of samples obtained by total sampling. Hemoglobin levels are measured by a Point Of Care Test (POCT). Results: in this study the results of statistical tests have been obtained $p$ value 0.276 which means $p>0.05$ in which obtained results that are not meaningful between prolanis exercises with changes in hemoglobin levels. Conclusion: the results obtained that there is no effect between prolanis exercises with hemoglobin levels. Because it can be caused by several factors such as the ineffectiveness of gymnastics, which is caused when gymnastics do not reach the value of the exercise zone in this study.
\end{abstract}

Keywords: Prolanis gymnastics, Hemoglobin levels, Training zone.

\begin{abstract}
ABSTRAK
Latar belakang: hemoglobin memiliki fungsi yaitu mentranspor oksigen. Latihan aerobik menyebabkan jaringan kekurangan oksigen. Hipoksia jaringan akan merangsang ginjal mengeluarkan hormon eritropoetin. Eritropoetin merangsang pematangan eritrosit dalam sumsum tulang. Sehingga akan menyebabkan peningkatan hemoglobin. senam Prolanis (Program Pengelolaan Penyakit Kronis) merupakan latihan jasmani aerobik yang merupakan salah satu program pemerintah. Penelitian ini ingin mengetahui pengaruh senam prolanis terhadap kadar hemoglobin sebelum dan sesudah senam. Metode: metode yang digunakan adalah kuasi eksperimen yang pembuktiannya diperoleh melalui perbandingan kondisi subjek sebelum perlakuan dengan sesudah diberi pelakuan dengan jumlah 16 responden. Dalam penelitian ini, jumlah sampel didapatkan dengan cara total sampling. Kadar Hemoglobin diukur dengan Point of Care Test (POCT). Hasil: pada penelitian ini hasil uji statistik telah didapatkan nilai $\mathrm{p} 0.276$ yang berarti $\mathrm{p}>0.05$ di mana didapatkan hasil yang tidak bemakna
\end{abstract}


antara senam prolanis dengan perubahan kadar hemoglobin. Kesimpulan: didapatkan hasil bahwa tidak terdapat pengaruh antara senam prolanis dengan kadar hemoglobin. Karena dapat disebabkan beberapa faktor seperti ketidak efektifan senam, yang disebabkan waktu senam tidak mencapai nilai zona latihan pada penelitian ini.

Kata kunci: Senam prolanis, Kadar hemoglobin, Zona latihan.

\section{PENDAHULUAN}

Hemoglobin adalah suatu protein terkonjugasi yang merupakan komponen utama dari sel darah merah yang mengandung hampir dua per tiga kebutuhan besi bagi tubuh manusia (1).

Hemoglobin juga merupakan kompleks pigmen - pigmen yang mengandung zat besi. Kompleks tersebut berwarna merah yang terdapat di dalam eritrosit. Sebuah molekul dari hemoglobin memiliki empat gugus heme yang mengandung besi fero dan empat rantai globin (2).

Fungsi dari hemoglobin yaitu untuk mengatur pertukaran oksigen dengan karbondioksida di dalam jaringan tubuh, serta mengambil oksigen dari paru-paru kemudian dibawa ke seluruh jaringan jaringan tubuh untuk digunakan sebagai bahan bakar, dan membawa karbondioksida dari jaringan - jaringan tubuh sebagai hasil metabolisme ke paru paru untuk dibuang (2).

Kadar normal hemoglobin pada pria adalah 14-18gr/dl, sedangkan pada perempuan 12-16gr/dl (3).

Peningkatan hemoglobin melalui latihan dihipotesiskan terjadi dengan seiring perubahan volume plasma yang berhubungan dengan latihan fisik. Perubahan ini membuat penurunan relatif dalam hemoglobin dan konsentrasi oksigen dalam darah arteri, sehingga merangsang eritropoiesis. Ketika tubuh kehilangan cairan karena berkeringat, hal ini dapat menyebabkan terjadinya penurunan volume plasma, sehingga menimbulkan peningkatan kadar hemoglobin secara relatif (1).

Latihan fisik pada senam prolanis yang bersifat aerobik dapat meningkatkan konsumsi oksigen. Oksigen berkaitan dengan hemoglobin sebagai protein pembawa yang berada dalam eritrosit untuk mencapai sel. Latihan fisik akan menyebabkan jaringan kekurangan oksigen. Hipoksia jaringan akan merangsang ginjal untuk mengeluarkan hormone eritopoetin. Eritropoetin merangsang eritropoiesis dalam sumsum tulang. Sehingga hal ini akan menyebabkan peningkatan eritrosit sekaligus hemoglobin saat melakukan latihan fisik (4).

Berdasarkan uraian di atas peneliti bermaksud untuk meneliti tentang pengaruh senam prolanis terhadap perubahan kadar hemoglobin sebelum dan sesudah senam.

\section{METODE}

Jenis Penelitian ini termasuk penelitian kuasi eksperimen yang pembuktiannya diperoleh melalui perbandingan kondisi subjek sebelum perlakuan dengan sesudah diberi perlakuan. Rancangan penelitian ini bertujuan untuk mengetahui pengaruh latihan senam pada program pengelolaan penyakit kronis (PROLANIS) terhadap kadar hemoglobin sebelum dan sesudah 
senam di klinik cempaka, jumlah sampel didapatkan dengan cara total sampling.

Total sampling adalah Teknik pengambilan sampel dimana jumlah sampel sama dengan populasi, apabila jumlah populasi kurang dari 100 maka seluruh populasi dijadikan sampel penelitian. Sampel yang diambil dari penelitian ini adalah 16 orang.

Metode pengumpulan data dalam penelitian ini dikumpulkan melalui data primer yang diperoleh dan dikumpulkan langsung dari sumbernya. Penelitian ini menggunakan beberapa instrumen penelitian yaitu Point of Care Test (POCT). POCT yaitu dilakukan dengan cara pengambilan darah perifer jari tengah yang sebelumnya dilakukan desinfeksi menggunakan alcohol swab. Selanjutnya darah dikeluarkan menggunakan lanset dan kemudian diukur kadar Hemoglobin.

Metode yang digunakan pada penelitian ini adalah analytic quasy experimental dengan pendekatan nonrandomized clinical trial untuk mengetahui kadar hemoglobin sebelum dan sesudah senam prolanis. Penelitian ini telah lulus uji kaji etik dari Komisi Etik Penelitian Kesehatan Fakultas Kedokteran dan Kesehatan (KEPK FKK) Universitas Muhammadiyah Jakarta.

\section{HASIL}

Tabel 1. Hasil Uji Normalitas

\begin{tabular}{lccc}
\hline & \multicolumn{3}{c}{ Shapiro Wilk } \\
& Statistik & Responden & $P$ Value \\
\hline $\begin{array}{l}\text { Hemoglobin } \\
\text { Sebelum }\end{array}$ & 0,966 & 16 & 0,775 \\
$\begin{array}{l}\text { Hemoglobin } \\
\text { Sesudah }\end{array}$ & 0,906 & 16 & 0,100 \\
\hline
\end{tabular}

Hasil uji normalitas pada Tabel 1 didapatkan data Saphiro Wilk menunjukan nilai $\mathrm{p}>0,05$ yang berarti normal sehingga dapat dilakukan uji parametrik yaitu uji $\mathrm{T}$.
Berdasarkan dari hasil penelitian pada Tabel 2, dapat disimpulkan bahwa tidak terdapat pengaruh yang bermakna antara senam terhadap kadar hemoglobin pada responden dilihat dari hasil Paired $T$ Test yang menunjukkan nilai significancy 0,276 yang mana $p$ value $>0,05$.

Tabel 2. Hasil Paired T-Test

\begin{tabular}{lccc}
\hline & Rata-rata & $\begin{array}{c}\text { Uji T } \\
\text { Standar } \\
\text { Deviasi }\end{array}$ & P Value \\
\hline $\begin{array}{l}\text { Hemoglobin } \\
\text { Sebelum }-\end{array}$ & 0,3813 & 1,3487 & 0,276 \\
$\begin{array}{l}\text { Hemoglobin } \\
\text { Sesudah }\end{array}$ & & & \\
\hline
\end{tabular}

\section{PEMBAHASAN}

Denyut nadi zona latihan yang efektif adalah Intensitas (220-usia) $=$ zona denyut nadi latihan. Sebagai contoh pada salah satu responden pada penlitian ini, usia responden adalah 73 tahun, dengan cara perhitungannya intensitas $80 \%$ (220-73) $=117$, maka denyut nadi zona latihan yang seharusnya responden capai adalah $117 \mathrm{x} /$ menit tetapi responden tersebut hanya mencapai $88 \mathrm{x} /$ menit yang berarti tidak mencapai zona latihan yang efektif.

Kurang lebih dari 70\% aktivitas fisik dari denyut nadi maksimal adalah intensitas yang berefektif untuk meningkatkan kebugaran jasmani, sedangkan diketahui bahwa intensitas dibawah $60 \%$ dari nadi maksimal hasil latihannya dinyatakan kurang efektif bagi kesehatan jasmani. Untuk mengetahui kefektifan dalam berolahraga dapat menghitungnya dengan rumus sebagai berikut : Intensitas $(220-$ Usia $)=$ target nadi latihan (5).

Dalam penelitian ini didapatkan bahwa tidak terdapat pengaruh yang bermakna terhadap peningkatan kadar hemoglobin. Menurut Güner Çiçek (2018), 
telah menemukan bahwa selama 8 minggu latihan aerobik pagi hari jumlah sel darah merah, kadar hemoglobin, dan persentase hemotokrit meningkat (6).

Pada penelitian ini hanya dilakukan senam selama 4 minggu, Hal yang dapat menjadi faktor tidak adanya pengaruh antara senam prolanis terhadap kadar hemoglobin, pada penelitian ini juga tidak dilakukan pemeriksaan ferritin serum sehingga tidak diketahui ferritin serum dalam tubuh dan pada responden kemungkinan adalah ketidak efektifan senam yang membuat responden menjadi tidak maksimal saat melaksanakan senam.

\section{KESIMPULAN}

Berdasarkan dari hasil penelitian yang telah dilakukan di Klinik Cempaka Jakarta Timur, dapat disimpulkan bahwa tidak terdapat pengaruh yang bermakna antara senam terhadap kadar hemoglobin pada responden.

\section{UCAPAN TERIMAKASIH}

Ucapan terima kasih kepada semua pihak yang telah berkontribusi dalam penelitian ini, sehingga penelitian ini dapat diselesaikan dan terlaksana dengan baik.

\section{KONFLIK KEPENTINGAN}

Pada penelitian ini tidak ada konflik kepentingan dengan organisasi apapun yang dapat menimbulkan pertanyaan atau bias hasil penelitian.

\section{REFERENSI}

1. Halim EV, Ticoalu SH., Wongkar D. Pengaruh Latihan Zumba Terhadap Kadar Hemoglobin. 2014;

2. Sheerwood L. Fisiologi Manusia. 9th ed. Jakarta: EGC; 2019.

3. Zainuddin A, Fahmy S, Sudiastuti. Kadar Nilai $\mathrm{Hb}$ (Haemoglobin)
Pendonor Sebelum Dan Sesudah Donor Darah du Unit Donor Darah Palang Merah Indonesia. Pros Semin Sains dan Teknol FMIPA Unmul. 2015;(September):10.

4. Oktawaty RS. Hubungan Keteraturan Senam Aerobik dengan Kadar Hemoglobin Peserta Senam Aerobik di Sanggar Senam D'ladies Gunung Pangilun. Fakultas Kedokteran Universitas Andalas; 2018.

5. Fakultas Pendidikan dan Kesehatan Universitas Pendidikan Indonesia. Olahraga kesehatan. Fakultas Pendidikan dan Kesehatan Universitas Pendidikan Indonesia. 2007.

6. Çiçek G. The Effects of Different Exercise Types on Hematological Parameters in Sedentary Women. J Educ Train Stud. 2018;6(8):96. 